\title{
居住環境と家事が慢性疼痛に及ぼす影響の調査と構造分析 COVARIANCE STRUCTURAL ANALYSIS AMONG LIVING ENVIRONMENT, HOUSEWORK AND CHRONIC PAIN
}

\author{
長 澤 夏子*, 堤 仁 美*, 松岡由紀子**, 加藤 龍 一** \\ 秋元孝之茥*，田辺新一 $* * * * *$ \\ Natsuko NAGASAWA, Hitomi TSUTSUMI, Yukiko MATSUOKA, \\ Ryuichi KATO, Takashi AKIMOTO and Shin-ichi TANABE
}

\begin{abstract}
The purpose of this paper is to consider the living environment for health promotion focusing on chronic pain such as the low back pain and shoulder stiffness, that many Japanese people suffer from. The questionnaire survey was conducted with 5000 adult women with a history of pain. Exploratory factor analysis revealed that living environment, activity of daily life including housework and chronic pain consisted of 27 items and five factors: " Chronic Pain ", " Stress and Fatigue ", " Total Hours of Housework ", " Enjoying Housework " and " Satisfaction of Living Environment".

Covariance structural analysis revealed the following thing. (1) Four subscales accounted for $73 \%$ of the "Chronic Pain." (2) "Stress and Fatigue" have affected "Chronic Pain" greatly. (3) "Enjoying Housework" and "Satisfaction of Living Environment" affected directly on "Chronic Pain" slightly. (4) However, more than it, "Enjoying Housework" and "Satisfaction of Living Environment" affected on "Stress and Fatigue" greatly. As a result, "Chronic Pain" is improved greatly indirectly.
\end{abstract}

Keywords : Health Promotion, Chronic Pain, Living Environment, Housework, Covariance Structural Analysis 健康増進，慢性疼痛，居住環境，家事 共分散構造分析

\section{1. 背景と目的}

\section{1. 住環境と健康}

近年、少子・超高齢社会の到来を背景として、健康への関心は高 まっている。内閣府が平成 22 年に実施した国民生活に関する世論 調查 1)では、悩みや不安の内容として、49.2\%の国民が「自分の健 康について」を、42.6\%が「家族の健康について」を挙げている。 また、水石ら ${ }^{2)}$ の調査では、 $85 \%$ の人が健康増進のために住宅が果 た寸役割は「とても重要である」または「まあ重要である」と認識 しており、健康を維持増進できる住宅が求められている。健康と環 境の関連については、WHO が健康都市(Healthy City)を提唱し、 人々の生活基盤である住宅やライフスタイルなども公衆衛生と同様 に、健康や QOL(Quality of Life)に関連していることが示されてい る。

身体症状と環境の関連についての研究には、シックハウスなどの ように建物が由来となる症状などについての多くの成果がある。ま た、東ら ${ }^{3)}$ 吉野ら ${ }^{4-5)}$ の研究でも、住環境やその周辺環境とアレル ギー疾患の関連についての可能性が指摘され、症状の由来となる可
能性のある環境の適切な整備による健康影響低減の方法が検討され ている。

更に、高橋ら 6) は高齢者を対象に、社会活動への参加や居住環境 が、QOL や主観的健康感に影響を与える可能性を、安藤ら7は、特 定地域の居住者への調査で、住宅や都市環境の物理的・社会的な満 足度が主観的健康感と関連している可能性を示唆している。高柳ら 8) は住環境の充実と主観的健康感の関連を、三徳 9) らは生活活動や 社会参加が心身機能や主観的健康感に関連寸る可能性を示している。

このように環境による健康への効果が明らかになれば、健康維持 増進のための建築や都市環境整備のアプローチが可能となり大変有 用である。しかし、健康維持増進と環境についての研究は緒につい たばかりで、成果の多くは、健康のパラメータとして主観的健康感 などの総合的な指標が用いられており、具体的な症状と環境、家事 などライフスタイルとの関連についての研究は少ない。

本研究では、健康のパラメータとして身体症状である慢性疼痛を 取り上げ、居住環境や家事など生活行動との関連を探る。

\footnotetext{
* 早稲田大学 客員講師 ·博士 (工学)

** 東京ガス

$* * *$ 農協共済総合研究所 理事 · 医博

**** 芝浦工業大学 教授・博士 (工学)

***** 早稲田大学 教授. 工博
}

Visiting Lecturer, Waseda University, Dr. Eng.

TOKYO GAS Co., Ltd., Inc.

Director, Nokyokyosai Research Institute, Dr. Med.

Prof., Dept. of Arch. and Build. Eng., Shibaura Institute of Technology, Dr. Eng.

Prof., Waseda University, Dr. Eng. 


\section{2. 慢性疼痛について}

疼痛（とうつう）とは痛みを示す言葉で、厚生労働省の調査 ${ }^{10)}$ で は、20 代以上の日本人が自覚症状を訴える上位 2 症状として、腰痛、 肩こりなどの慢性疼痛があげられている。腰痛、肩こりは男性より も女性に多く、年齢が上がるほどその割合が高い。他の大規模調査 11)によれば、慢性疼痛の有病率は全成人の $22.5 \%$ 、推定患者数は 2,315 万人である。しかし、腰痛の $80 \%$ 以上が医師の診断で原因が 特定しきれないことが報告されており12)、肩こりも同様に殆ど病態 は解明されていない。近年、腰痛、肩こりなどの身体症状の原因に は心理・社会的要因や、運動不足なども関係しているという医学的 な知見が得られており 13-16)、適度な運動やストレス軽減が症状の悪 化を防ぎ、予防につながると期待されている。

\section{3. 慢性疼痛と住環境・家事など生活行動}

日常生活の中で慢性疼痛は、運動不足や筋力の低下、さらに精神 的ストレスなどの個人因子と、作業環境や作業姿勢などの環境因子 に大きく影響を受けていることが指摘されている。そのため、環境 因子のハードとしての住環境とソフトとしての家事など生活行動は、 慢性疼痛やそれに影響を受ける QOL、ADL(Activities of Daily Living)の重要な規定要因と考えられる 17-18)。

労働環境における運搬など重度の負荷や、長時間の無理な姿勢は 疾患の危険因子だと指摘されている。住宅では特定の日常生活動作 中の足腰肩など関節への負担計測や、腰痛者への聞き取り調查など 19-22)が行われ、空間特性と身体負担の関係は明らかになってきてい るが、症状との関連報告は少ない。一方、腰痛や膝痛などの疫学調 查で、外出時に階段をよく利用する人は新たな腰痛の出現が少ない という健康増進効果も報告されている23)。しかしこれまで慢性疼痛 の悪化や改善と、居住環境・家事など生活行動の関係性については 大規模な調查は行われていない。

本研究では、居住環境・家事など生活行動が慢性疼痛に影響する という仮説を証明し、その影響度を定量的に把握し、慢性疼痛の改 善要因を推測することを目的とした。家事を含んだ生活行動を広く 検討したが、本稿では、構造分析では健康と住まい、家事を特に注 目すべき因子として取り上げた。

2. 慢性疼痛（腰痛・肩こり）と居住環境 - 家事など生活行動に関す るアンケート調査

\section{1.方法と対象}

会員登録をしている一般生活者へのインターネットリサーチによ るアンケート調査注 1 をを行った。調査対象者の条件を表 1 に示す。

表 1 調查対象者の条件

\begin{tabular}{c|c}
\hline 性別 & 女性 \\
\hline 既往症 & これまでに腰痛か肩こりを経験（どちらかあるいは両方） \\
\hline 就労と家事 & 就労時間が週に 40 時間未満かつ家で主に家事を担当 \\
\hline ライフスタイル & 1 年以上同じ家に居住し、大きなライフスタル変化なし \\
\hline その他 & 要介護認定、障害者認定を受けていない \\
\hline 年齢構成比 & 25 歳以上で、日本の人口比率 7 に近くなるように割付 \\
\hline
\end{tabular}

居住環境や家事など生活行動と症状の関連を見るために、腰痛ま たは肩こり既往者の女性で、就労時間が短く主に家事を担当してい る人とした。また、 1 年以上の間、同じ家に居住し介護や出産など の大きなライフスタイルの変化がない人とした。調査は、2011 年 2
月 18 日（金）から 27 日（日）までの間に実施され、19,671 名へ のスクリーニング調査で対象としての適性が確認された回答者、計 5,000 名から有効回答を得た。

\section{2. 調査項目}

表 2 に示すとおりアンケート項目は、「I. 被験者の属性」「II．居 住環境」「III. 家事など生活行動とストレス」「IV. 慢性疼痛（腰痛・ 肩こり) それぞれの症状・健康感」「V. 特定の作業や動作と腰・肩・ 全身の症状」の 5 つで構成した。

\section{表 2 アンケート項目}

\section{被験者の属性}

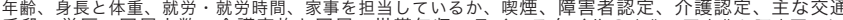

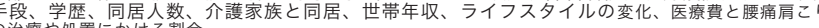
II 居住環境

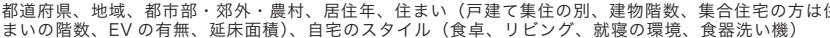

自宅の環境(キッチン高さ、キッチン広さ、脱衣高さ1高すぎる2）やや高い3)ちょうどいい 4)やや 等広さ、浴室広さ)

\section{家事など生活行動とストレス}

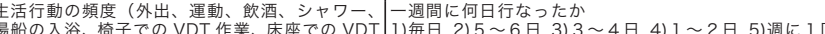

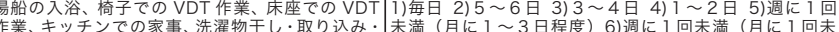

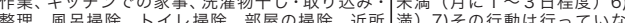

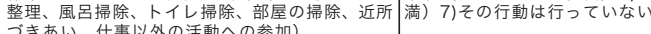

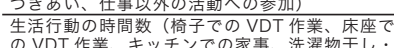

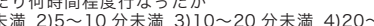
取り込み・整理、風吕掃除、トイレ掃除、部屋の 30 分未满5)30 60 分未满 6)1 3 時間末满 7)3 5

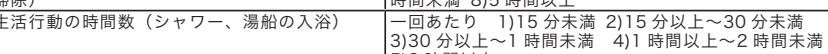
\begin{tabular}{l|l}
\hline 階段昇降の週当たりの行動量 & 572 時間以上 \\
\hline
\end{tabular}

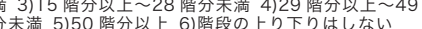

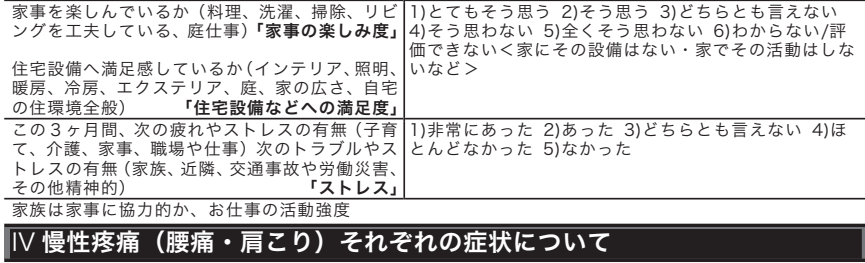

腰痛・肩こりの経験の有無

腰痛・肩こりの症状（いつ頃から、きっかけ、治療や処置、症状に対する活動制限、おこる季節）

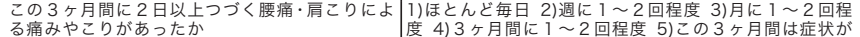

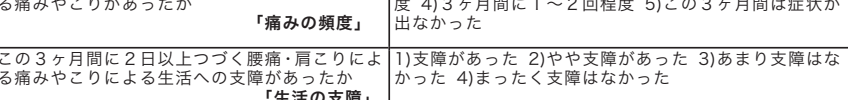

\begin{tabular}{|c|c|}
\hline $\begin{array}{l}\text { この3ヶ月間で最も強かった腰痛・肩こりによ強度」やこる } \\
\text { 痛みやは何点か }\end{array}$ & $\begin{array}{l}10 \text { 点満点で何点か }(0 \text { は痛み無し、1 は最小、10 は } \\
\text { これ以上痛み) }\end{array}$ \\
\hline この3ヶ月間の全身の疲労感 & 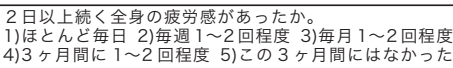 \\
\hline 主観的な健康感 & $\begin{array}{l}\text { 1)とても健康である 2)まあまあ健康である 3)あまり健 } \\
\text { 康ではない侓康でない }\end{array}$ \\
\hline 睡眠 & $\begin{array}{l}\text { 1)よく眠れている2)時々眠れないときがある 3)常に不 } \\
\text { 眠である(眠れない) }\end{array}$ \\
\hline $\begin{array}{l}\text { この3 ケ月間での腰痛・肩こりの主観的な症状傾 } \\
\text { 向 }\end{array}$ & 1)改善している 2)変化がない 3)亜化している \\
\hline
\end{tabular}
その他

\section{V 特定の作業や動作と腰・肩・全身の症状}

1日の家事が終わると、全身の疲労感を感じたか この3ケ月間、動作時に感じる腰の負担

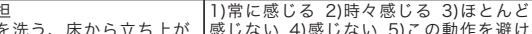

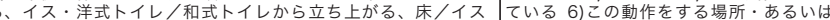
やソファに座っている、階段を上る/下りる、高いところ/低

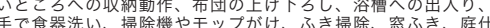
事)

③ヶ月間、動作時に感じる肩の免担

（高いところの収納動作、低いところへの収納動作、布団の上 壮ろし、手で食器洗い、墇除機やモッフがけ、ふき揭除、 交き、庭社事)

家事などの作業後に腰に負担・肩に負担（こりや痛み）を感じ 1 1)負担を感じて作業を中止することがあ

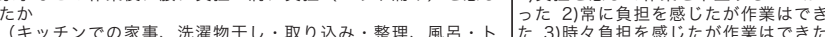

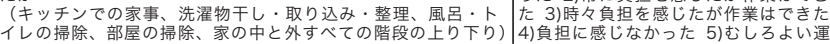
1 日の家事が終わると、腰に負担・肩に負担（こりや痛み）

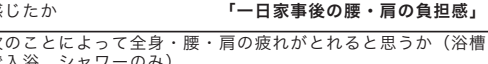

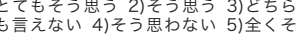
思わない 6)わからない/評価できない 家にその設備はない・家でその活動は 
I では、被験者の年代ごとに日本の人口構成比率 ${ }^{24)}$ に近くなるよ うに割付けを行った。II では居住環境についての質問、III では、 運動としての家事を捉えられるように、頻度や時間数といった量と して聞き、総時間などが推計できるようにした。IV は疼痛の重症度 を知るための質問である。腰痛・肩こりの定義は注 2)に記す。腰痛・ 有こりなどは、そもそも断続的に症状があらわれるものであること から、「この 3 ケ月」についての、痛みやこりの頻度、痛みの強度、 症状による生活の支障などを指標とした。疫学調査で用いられた方 法を参考に質問方法を採用した ${ }^{3}$ 3)。V は、住宅内での特定の動作を 行ったときに、負担感の大きい動作がなにかを知るために、作業や 動作の時の症状について聞いている。また各家事の作業後に感じる 腰や肩、全身の負担感や、湯船やシャワーなどでの改善感なども尋 ねた。

\section{3.回答者の属性}

\section{3. 1. 回答者の年代}

図 1 は回答者の年代構成で、日本の構成比 ${ }^{25}$ に即しているが Web 調査の特性上、65 歳以上の割合のみやや少ない。

\section{3. 2. 腰痛·肩こり経験者}

スクリーニング前の 19,671 人について、腰痛経験者は $74.3 \%$ 、 肩こり経験者 $82.9 \%$ 、両方経験者 $66.5 \%$ 、両方なし $9.3 \%$ であった。 日本整形外科学会の腰痛に関する日整会プロジェクトの報告 26)に よると、これまでの生涯における治療を要するほどの腰痛の経験率 は、女性の場合 $51.1 \%$ である。本調査では、腰痛・肩こり経験者の 条件に「治療を要するほどの」という制約を設けなかったことから 既往の他の調查と比べて、既往者の割合が高い結果であったと考え られる。

\section{3. 3. 腰痛·肩こり頻度}

図 2 に腰痛・肩こり頻度の回答結果を示寸。この 3 ケ月間に 2 日 以上続く腰痛による「痛みやこり」があった人は 8 割、肩こりによ る「痛みやこり」があった人は 9 割であった。

\section{3. 4. 腰痛·肩こり強度}

図 3 に腰痛・肩こり強度の回答結果を示寸。「痛みなし」が 0 、「想 像できる最高の痛み」を 10 として、この 3 ケ月間に感じられた痛 みについての強度を聞いた注3)。この 3 ケ月間で、最も強かった腰 痛または肩こりによる「痛みやこり」を点数化してもらったところ、 0 点から 10 点まで分散していた。

\section{3. 5. 居住環境についての満足度}

図 4 に各居住環境についての満足度を示す。冷房、暖房、自宅の 広さ、住環境全般についての満足度について、とてもそう思う、そ う思う、と回答した人が 4 割以上と多かった。

\section{3. 6. 家事の楽しみ}

図 5 に家事の楽しみについての回答結果を示す。リビングをくつ ろげるように工夫しているかとの質問に、とてもそう思う、そう思 う、と回答した人が 5 割と多かった。また庭仕事が気分転換になる かとの質問については、「わからない、評価できない（家にその設備 はない、家でその活動はしないなど)」との回答が 3 割を占めた。料 理を楽しんでいる、洗濯などの家事を楽しんでいる、掃除などの家 事を楽しんで行なっている、についての回答は、分散していた。

\begin{tabular}{|c|c|c|c|c|c|c|c|}
\hline & & $20 \%$ & $40 \%$ & $60 \%$ & $80 \%$ & & $100 \%$ \\
\hline $\begin{array}{l}\text { 平成 } 23 \text { 年 } 10 \text { 月 } 1 \text { 日現在 } \\
\text { 日総人口(女) }\end{array}$ & $16 \%$ & $21 \%$ & $17 \%$ & $21 \%$ & $9 \%$ & $8 \%$ & $8 \%$ \\
\hline 本調查 $(\mathrm{N}=5000)$ & $19 \%$ & $19 \%$ & $18 \%$ & $27 \%$ & & $12 \%$ & $5 \% 1 \%$ \\
\hline
\end{tabular}

図 1 回答者の年代

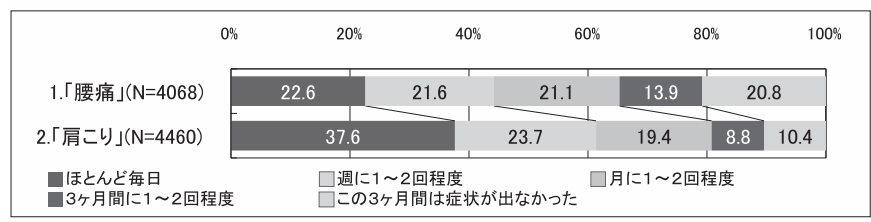

図 2 腰痛・肩こりの頻度

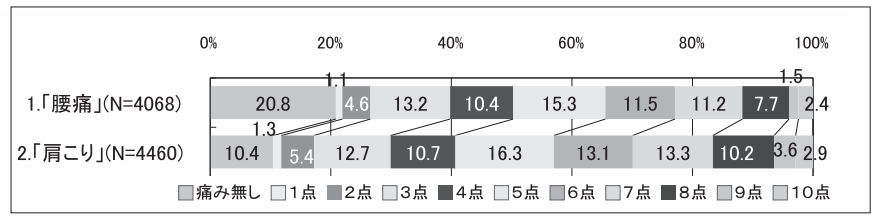

図 3 腰痛・肩こりの強度

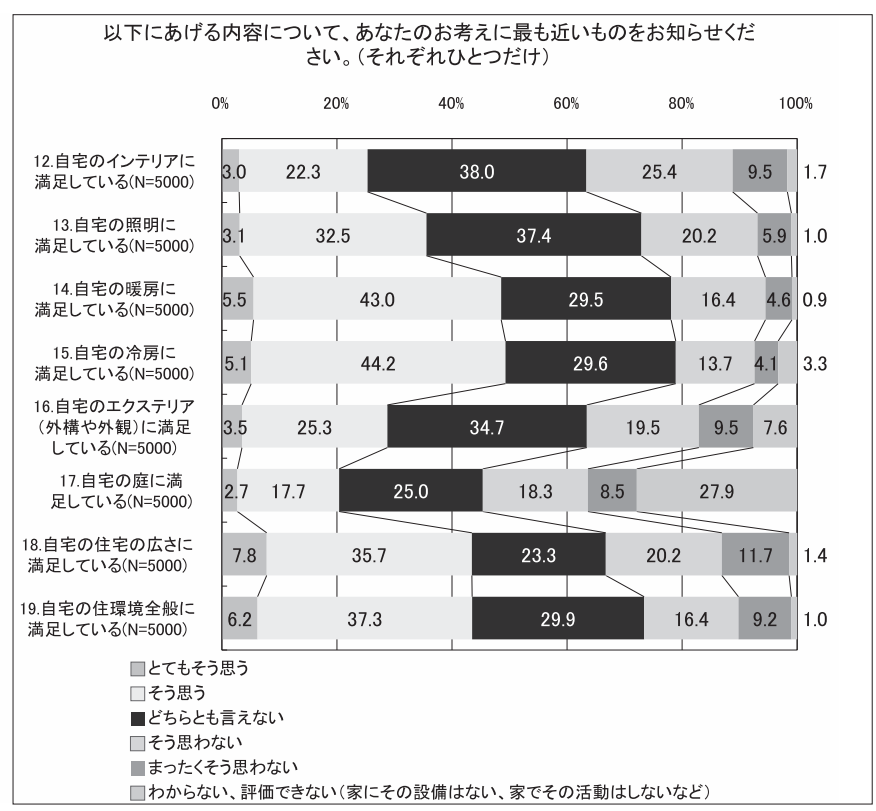

図4 居住環境についての満足度

以下にあげる内容について、あなたのお考えに最も近いものをお知らせく ださい。(それぞれひとつだけ)

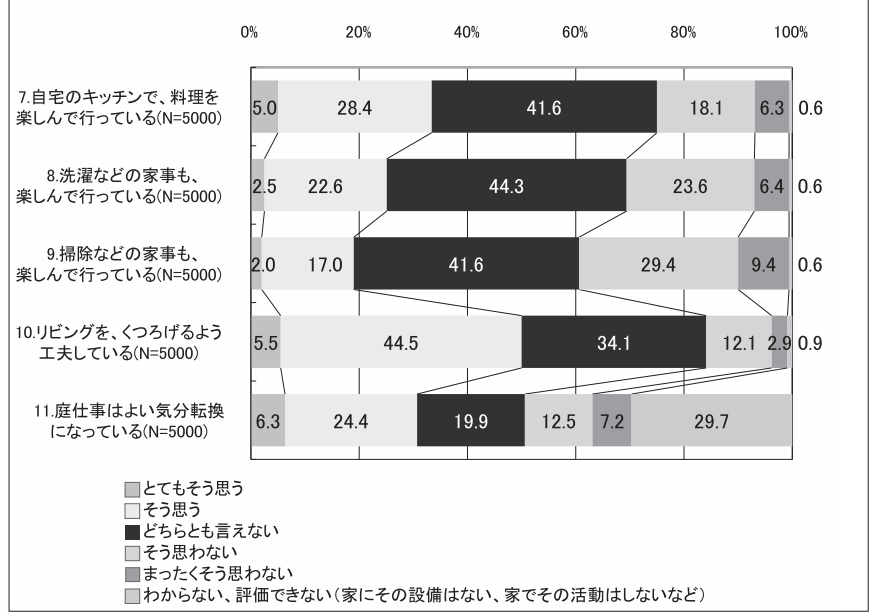

図 5 家事の楽しみ 


\section{3. 7. 家事の時間}

図 6 に家事の 1 週間あたりの総時間についての集計結果を示す。 総キッチン時間が、他の家事時間と比べてとても長い傾向にある。

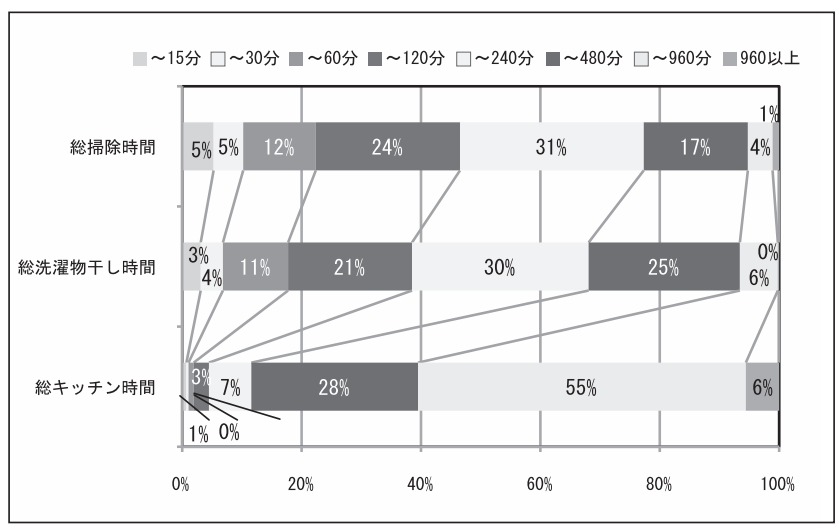

図 6 家事の時間 $(1$ 週間当たりの時間数)

\section{3.共分散構造分析による慢性疼痛モデル}

\section{1. 分析方法}

居住環境・家事など生活行動が慢性疼痛に影響するという仮説を 証明し、その影響度を定量的に把握することを目的に、共分散構造 分析を行った注4)。腰痛または肩こりの経験があり、それぞれの症状 について手術した経験や手術する予定の無い 4,967名を解析対象と し、下記の手順で解析を行った。統計分析ツールにはSPSS Statistics 19 とAmos 19 を用いた。

(1) 観測変数の検討

全アンケート項目から居住環境·家事など生活行動に関する項目、 および腰痛・肩こりに関する項目やストレスなど健康に関わる項目 を抽出した注 ${ }^{5)}$ 。必要な場合、類似した質問内容については合成変数 を作成した注 6)。

その中から居住環境・家事など生活行動に関わる項目に対してプ ロマックス回転を用いた最尤法による探索的因子分析を行ない、共 通性を参考に 13 項目の変数を決定した。その結果、『住まいの満足』 『家事の楽しみ』『家事の時間』の 3 因子が抽出された。また健康 に関わる項目に対しても、同様にして 14 項目の変数を決定し、『ス トレス・疲労感』『慢性疼痛』の 2 因子が抽出された。これら 27 項 目、計 5 因子で共分散構造のモデル化を試みる。

(2) 慢性疼痛に関連する共分散構造分析のモデル化

『慢性疼痛』は、「腰痛による生活の支障」「腰痛の強度」「腰痛の 頻度」「1 日家事後の腰の負担感」「肩こりによる生活の支障」「肩こ りの強度」「肩こりの頻度」「1 日家事後の肩の負担感」の 8 つよ り評価された。『ストレス・疲労感』は「1 日家事後の全身疲労感」 「慢性疲労感」「家事のストレス」「家族のストレス」「その他の精神 的ストレス」「主観的健康感」の 6 つにより評価された。なお「慢 性疲労感」は『慢性疼痛』『ストレス・疲労感』の両方で因子負荷量 が高かったが、今回は『ストレス・疲労感』に含めた。また「主観 的健康感」の因子負荷量はやや小さかったが重要な因子として残し た。

『住まいの満足』は「エクステリアの満足度」「庭の満足度」「住 環境の満足度」「住宅広さの満足度」「照明の満足度」「インテリアの
満足度」「暖冷房の満足度注6」」の 7 つにより評価された。『家事の楽 しみ』は「洗濯の楽しみ度」「掃除の楽しみ度」「料理の楽しみ度」 の 3 つにより評価された。『家事の時間』は「洗濯物干時間」「キッ チン作業総時間」「掃除総時間」注6)の 3 つにより評価された。 $\alpha$ 係数注 7)を表 3 に示す。いずれも 0.5 以上で信頼性は高かった。

表 3 信頼性統計量 $\alpha$

\begin{tabular}{l|l}
\hline 『住まいの満足』 & .868 \\
\hline 『家事の楽しみ』 & .877 \\
\hline 『ストレス・疲労感』 & .747 \\
\hline 『慢性疼痛』 & .732 \\
\hline 『家事の時間』 & .643 \\
\hline
\end{tabular}

(3) 適合度と誤差変数間の相関パスの検討

因子相関を基にパス図を用いて仮説を表現し、共分散構造分析を 行った。モデルの適合度の指標には CFI ${ }^{\text {注 8) }}$ 、IFI ${ }^{\text {注 9) }}$ 、 RMSEA ${ }^{\text {i玉 }}$ 10) の 3 種類を使用し、モデルの採択基準は、CFI と IFI は 0.90 以上、 RMSEA は 0.05 以下とした。パス係数は有意水準 $5 \%$ で有意性を判 断した。

また、『住まいの満足』『家事の楽しみ』『家事の時間』『ストレス・ 疲労感』を構成する観測変数については、修正係数に基づいて、誤 差変数間に意味の上でも共分散の設定が認められるものについて、 相関パスを作成した。また、『慢性疼痛』を構成する観測変数に付随 する誤差変数間の相関パスについては、臨床上の知見より、腰痛に 関連する 3 变数（「腰痛による生活の支障」「腰痛の強度」「腰痛の 頻度」）は互いに関連すること、また、「1 日家事後の腰の負担感」 は「腰痛による生活の支障」に関連することから相関パスを作成し た。肩こりに関連寸る 3 変数（「肩こりによる生活の支障」「肩こり の強度」「肩こりの頻度」）も同樣に互いに関連すること、また、「1 日家事後の肩の負担感」は「肩こりによる生活の支障」に関連寸る 事から相関パスを作成した。更に、痛みの感じ方などについては個 人差があることが知られており、腰と肩という部位が異なっても、 痛みの強度、痛みの頻度、痛みによる支障、負担感などはそれぞれ が関連することが推察されることから誤差間に相関パスを作成した。

\section{2 慢性疼痛モデルの検討結果}

3.1 で示した手順で作成した、『住まいの満足』『家事の楽しみ』『家 事の時間』『ストレス・疲労感』『慢性疼痛』の 5 つの因子からなる モデルを図 7 に示す。観測変数間のパス係数は全て有意であった。 調查した多くの生活行動の中でも家事が大きく影響していることが わかった。

『慢性疼痛』の決定係数は 0.73 となり、『慢性疼痛』の $73 \%$ を住 まいの満足』『家事の楽しみ』『家事の時間』『ストレス・疲労感』で 説明できることがわかった。

『ストレス・疲労感』から『慢性疼痛』へのパス係数は 0.92 で、 ストレス・疲労感と慢性疼痛は強く関連していた。

『住まいの満足』は、『家事の楽しみ』を増や寸方向に 0.44 と高 度の影響を、『ストレス・疲労感』を減らす方向に 0.27 と中度の影 響を与えていた。また、『家事の楽しみ』は『ストレス・疲労感』を 減ら寸方向に 0.21 と中度、『家事の時間』を増や寸方向に 0.12 と低 度の影響を与えている。『家事の時間』は『ストレス・疲労感』を増 やす方向に 0.22 と中度の影響を与えていた。 


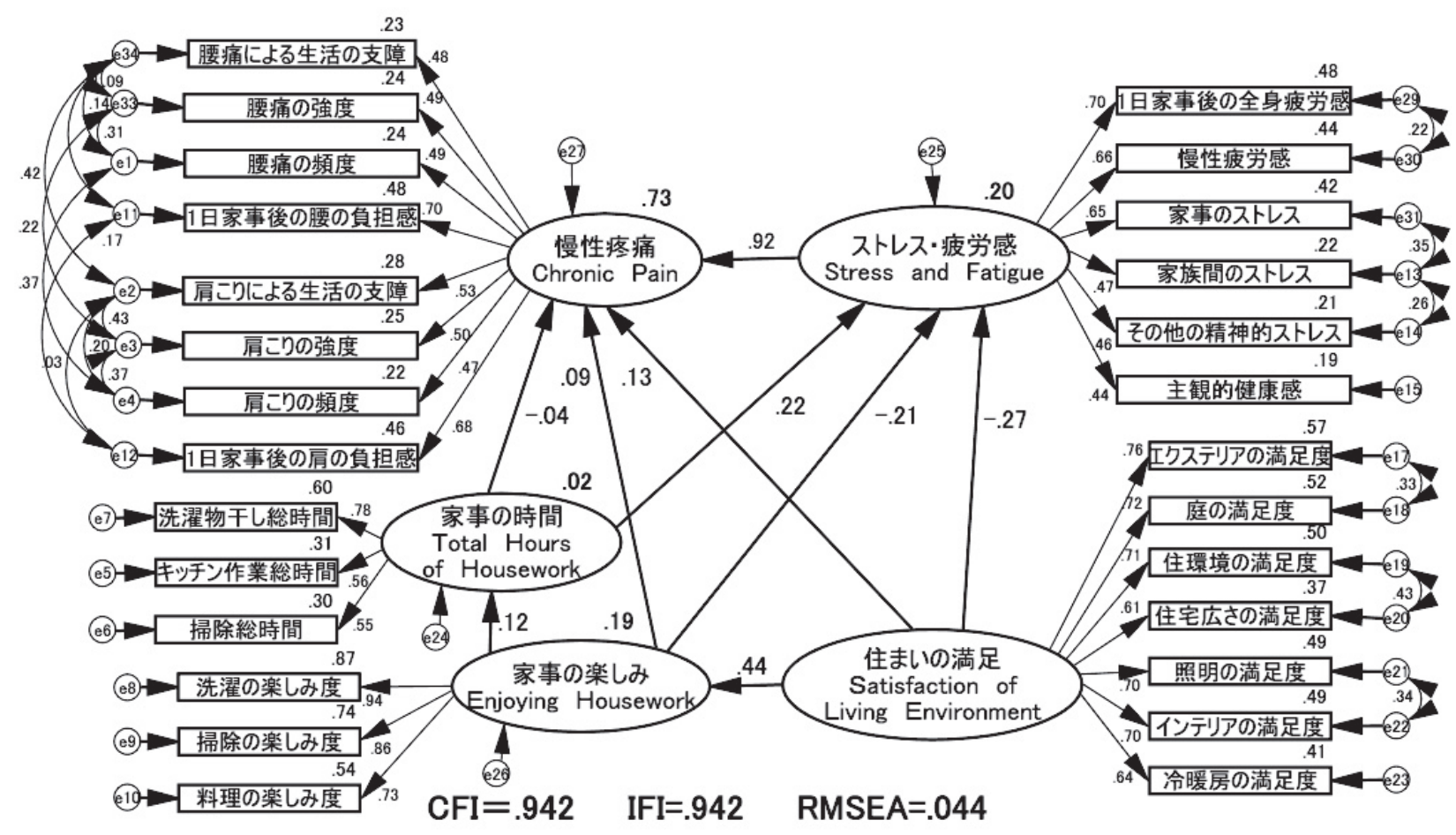

図 7 慢性疼痛モデル（標準化推定值）

『住まいの満足』と『家事の楽しみ』は、『慢性疼痛』に直接的に は 0.13、0.09 とわずかに悪化の方向に影響を与えているが、『住ま いの満足』と『家事の楽しみ』は、それぞれ『ストレス・疲労感』 を介することにより、間接的に『慢性疼痛』を改善させる方向に 0.25 $(0.27 \times 0.92) 、 0.19(0.21 \times 0.92)$ と直接効果よりも強い影響を与 えていた。加えて、『家事の時間』が長いと、直接には 0.04 とわず かに『慢性腰痛』を減らす方向に影響を与えているが、『ストレス・ 疲労感』を介した間接効果では $0.20(0.22 \times 0.92)$ と、慢性疼痛を 増や寸影響があることがわかった。これは『家事の時間』を日常生 活の中の運動と見なして『慢性疼痛』への影響をみたが、明確な結 果は得られなかった。

以上から、居住環境に対する満足度を高め、家事を楽しむ環境が、 ストレス・疲労感を介して、慢性疼痛を減少させる可能性が示された。

\section{4. まとめ}

本研究では、健康維持増進できる住宅について、疼痛の既往者の 女性 5,000 名への調查から居住環境・家事など生活行動が疼痛、ス卜 レス等に与える影響を検討した。

居住環境や生活行動と腰痛肩こりといった慢性疼痛について、ア ンケートによって、住まいの満足度や、家事の楽しみ度といった 5 段階での質問を作成し、定量的にデータを得た。

アンケート結果を用いて 5 因子の共分散モデルを作成し、その結 果、『慢性疼痛』は、4つの潜在変数『ストレス・疲労感』『住まい の満足』『家事の楽しみ』『家事の時間』で $73 \%$ が説明できる事が分 かった。特にストレスが慢性疼痛に $92 \%$ と大きく関連していること が示された。また、得られたパス係数の数值は疼痛悪化（改善）に 対する影響度を示している事から、モデルで示されたそれぞれの変
数は、改善すべき因子の重要度とみることができる。『住まいの満足』 『家事の楽しみ』は『慢性疼痛』に対して直接的にはわずかに悪化 の方向に影響を与えるが、それ以上に、『住まいの満足』が向上する と『ストレス・疲労感』が直接効果で減り、また『家事の楽しみ』 を介した間接効果も加わって減少し、結果として『慢性疼痛』が減 少することが定量的に示された。

以上により、居住環境に対する満足度を高め、家事を楽しむこと のできる環境が、ストレス・疲労感を減らし、慢性疼痛を減少させる 可能性が示された。

これまで、主観的健康感などと環境との関連が示唆されていたが、 本研究によって、具体的な身体症状である慢性疼痛と環境整備との 関連が示すことができた。今後は、具体的な疾患別の環境整備方法 や、対象者別の効果などについて、より詳細な分析が必要である。

謝辞

本研究は、国土交通省に設置された「健康維持増進住宅研究委員会 (委員長 : 村上周三)」ならびに一般財団法人建築環境・省エネルギ 一機構に設置された「健康維持増進住宅研究コンソーシアム (会長 : 村上周三、民間機関 19 社で組織、国土交通省支援)」の活動の一環 として実施したものである。調查にご協力をいただいた各位、ご助 言・ご指導をいただいた委員会等関係者各位に感謝の意を表します。

注

注1）本調查は、インターネットリサーチ会社を通じて web 調査を行なった。 リサーチ会社では、多くのアンケートに回答してもらうために一般生活者 を会員登録しており、その方を対象とした。会員はアンケートー回答する ことにより、一定の報酬が得られる仕組みである。本調査に協力いただい 
た会員の属性について、補足すると、2012/08/01 現在、全体の有効モニタ 一数は 506,766 人であり、男女比、年齢層比、職種、居留地 など概ね日 本の人口構成比に近い。その会員にスクリーニング調査への参加を呼びか けて一定数に達したとところで終了し、その中から条件にあった 5,000 名 を選んだ。

注2）腰痛肩こりの定義 : 本調査では腰痛および肩こりについて、次のように 定義し図を明示の上、アンケートを行った。

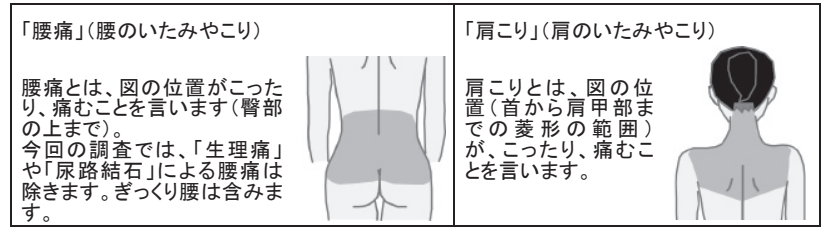

注3）症状についての質問について:肩こりについて、疫学分野でも調査が少 ないことから、腰痛・肩こりを同時に並列で慢性疼痛の代表として調査 するために、オリジナルの質問を作成し、【痛みの強度】【症状の頻度】 【症状による生活の支障】【1 日家事後の腰・肩の負担感】の 4 つが、本 調査に必要と判断した。

【痛みの強度】については、疼痛強度を表現するスタンダードとして、VAS を参考にNRS を使用した。ペインクリニック学会によれば、疼痛の評価 で最も広く用いられているのが Visual Analogue Scale(VAS) であり、 本調査でもスケールの入った長い黒い線（左端が「痛みなし」0、右端が 「想像できる最高の痛み」10）を回答者に提示し、現在の痛みがどの程度 であるかという質問をした。その上で、整数で回答してもらえるように、 この VAS と似た方法として知られる、Numerical Rating Scale を採用し て（0１0 までの 11 段階でどの程度か）の一番近い数字を、回答させ た。つまりスケール線を見ながら、整数で回答してもらった。また本質 問は「（この 3 ケ月間に）腰痛、または肩こりによる痛みがある」と答 えた人のみに行なったため、選択肢の 0 を除いた、1〜10 までの 10 段階 で回答してもらっている。「痛みがない」と答えた人は、自動的に0と した。なお、紙面回答の場合、VAS で用いられる線の幅は $10 \mathrm{~cm} 、 20 \mathrm{~cm}$ 、 などとされているが、今回はインターネット調査のため、web 画面上で 提示された長さは環境により異なった。

次に、3 月以上続く痛みを想定して、腰痛、肩こりの全既往者から最近 の 3 ケ月間での【症状の頻度】および【症状による生活の支障】を独自 の方法で聞いた。頻度に関しても文献が少ないが、週 2 回以上の痛みが 3 ヶ月続くと慢性の疼痛と定義しているものが多い（文献 11 など）。

また【腰痛肩こりの頻度】は、腰痛・肩こりなどは、そもそも断続的に 症状があらわれるものであることから、く現在、症状がある>という状 況を確定するために、「この 3 ケ月」について $(2$ 日以上続く、痛みやこ り)があることとし、その頻度はどのくらいであるかを 5 段階で聞いた。 【症状による生活の支障】については本調査が、主に家事を担当している 人を対象とした事から、腰・肩の疼痛によって生活に支障があったかを 4 段階で質問している。

疼痛に関して【症状による生活の支障】については、ローランド・モー リスやそれを基にした JLEQ、JOABPEQ の質問の一部などがあるが (文 献 $32,33,34$ 参照）いずれも質問量が多く、また一部抜粋では使用できな いことから、単純化したオリジナル質問を使用した。

【1 日家事後の腰、肩の負担感】は、適度な負荷が腰痛、肩こりに良好な 影響を与える可能性を考え、独自の質問（主に家事を担当している人を 対象とした事から、家事後の腰・肩の負担感を 5 段階で質問）を作成し た。

注4）本モデルでは、居住環境や生活行動・症状について、住まいの満足度や、 家事の楽しみ度といった 5 段階での質問を作成し、定量的にデータを得た。 （定量的な質問でないものは、本モデルには適用できないため用いていな い。）「共分散構造分析」の専門解説によれば、「共分散構造分析」では、 直接観測できない『潜在変数』を導入することで, 潜在変数と観測変数と の間の因果関係を同定することによって、社会現象や自然現象を理解する ための統計的アプローチである、とされる。モデルの中の『家事の楽しみ』 『住まいの満足』という表現は、質的な評価のように見えるが、観測した変 数のまとまりごとに名前を付けた『潜在変数』であり、これを用いて、「観 測変数」の構造的なつながりを知ることができる。また、これらのパス係 数の数值は、改善すべき因子の重要度とみることができ、さらに、その『潜 在変数』から影響される観測変数の度合いも定量的に求められることから、 改善要因を推測する事が可能となる。
注5) 疼痛の欠損について: 本調査では腰痛または肩こりのどちらかの既往者 を対象としているため、例えば肩こり既往者で回答しているが、腰痛は既 往でない人は腰痛関連項目に関して回答がない。これらは既往者で現在症 状がない人と区別するため欠損值として扱った。

注6）観測変数と合成変数 : 観測変数の多くは、表 2 に示したアンケートの回 答結果の值を用いた。『ストレス・疲労感』『慢性疼痛』に関わるものは 症状が悪い方向に数值が大きく、また、『住環境満足度』は満足度が高い 方が、『家事の楽しみ』は楽しみが大きい方が、『家事の時間』は家事時 間が長い方が、数值が大きくなるように変換した。またアンケートの回答 より合成変数を作成したものは以下である。

(1)家事の時間について：「掃除の総時間」は、風呂掃除、トイレ掃除、部 屋掃除の $3 つ の$ 回答を足し合わせたものである。「キッチンの総時間」「掃 除の総時間」「洗濯物干総時間掃除」は、それぞれの（生活行動の一日の 時間数) に（1 週間の生活行動の頻度）をかけて（1 週間あたりの時間数） になるように求めた。この際、アンケート回答は幅のある選択肢であった ことから、(生活行動の一日の時間数）はそれぞれ、1) 2.5 分 2) 7.5 分 3) 15 分 4) 25 分 5) 45 分 6) 120 分 7) 240 分 8) 360 分 とし、 (1 週 間あたりの時間数）はそれぞれ、1 週間の頻度 1) 7 日 2) 5.5 日 3 日) 3.5 日 4) 1.5 日 5) 0.5 日 6)および 7) 0 日 として計算した。求めた值を、再 度次の 8 值に分けた。1) 15 分未満 2) 30 分未満 3) 60 分未満 4) $\sim 120$ 分未満 5) 240 分未満 6) ４80 分未満 7) ～960 分未満 8) 960 分以上

(2)「冷暖房満足度」について: 冷房満足度と暖房満足度を足し合わせた。

注7） $\alpha$ 係数：測定の安定性を表す信頼性の推定值。0 1 の值をとり、1に近 いほど信頼性が高い。0.5 以上で信頼性が高いとされる

注8) CFI : Comparative fit index, $0 \sim 1$ の間の值をとり、1 に近いほど適合 がよいと判断する。概ね 0.9 以上で適合度がよいとされる。

注9) 注 6) IFI : Bollen's incremental fit index, 0〜1 の間の值をとり、1 に近いほど適合がよいと判断する。概ね 0.9 以上で適合度がよいとされ る。

注10) RMSEA: Root Mean Square Error of Approximation, 0 以上の值をとり、 0 に近いほど適合がよく、0.1 以上で適合度が悪いと判断される。

\section{参考文献}

1)内閣府：国民生活に関する世論調査，第 2 章，2010

2) 水石仁他：居住環境における健康維持増進に関する研究 (その 2) 健康増進 における住宅の役割に関する生活者の認識調査, 日本建築学会大会学術講 演梗概集 D-1 分冊, pp. 993-994，2009

3) 東賢一他：埼玉県における居住環境とアレルギー性疾患の関連性に関する 調查研究，日本建築学会環境系論文集，第 584 号, pp. 83-90, 2004.10

4) 吉野博他：シックハウスにおける室内環境と居住者の健康に関する調査研 究 (その 1) 宮城県内の 62 軒の住宅における調査結果, 日本建築学会環境系 論文集, 第 74 巻 第 641 号, pp. 803-809, 2009.7

5) 吉野博他：シックハウスにおける室内環境と居住者の健康に関する調査研 究 (その 2) 宮城県内の 30 軒を中心とした住宅における長期継続観察, 日本 建築学会環境系論文集, 第 75 巻 第 654 号, pp. 705-712, 2010.8

6) 高橋俊彦, 星旦二他 : 生活実態調查に基づく高齢時代の健康づくりとコミュ ニティ活動の関連性--多摩市在宅高齢者の健康規定要因の構造分析に関す る研究, 多摩ニュータウン研究 (6), pp. 2-9, 2004

7) 安藤真太朗他：共分散構造分析に基づく青壮年期・高齢期の健康形成要因 構造モデルの提案-北九州市郊外住宅地における住宅・地域環境の健康決定 要因に関する研究 (その 1), 日本建築学会環境系論文集, 第 76 巻 第 664 号, pp. 573-580, 2011.6

8) 高柳絵里他：健康維持増進に向けた住環境評価ツールの有効性の検証, 日 本建築学会環境系論文集, 第 76 巻 第 670 号, pp. 1101-1108, 2011. 12

9) 三徳和子, 星旦二他: 高齢者の健康関連要因と主観的健康感, 川崎医療福祉 学会誌 $15(2)$, pp. 411-421, 2006

10) 厚生労働省 : 平成 22 年国民生活基本調査の概況, 第 3 章, 2010

11) 矢吹省司他：日本における慢性疼痛保有者の実態調查、臨整外 47,pp. 127 $\sim 134,2012$

12) Deyo Ra. et al : What can the history and physical examination tell us about low back pain?, JAMA 268, pp. 760-765, 1992

13) 松平浩: 産業医に役立つ最新の研究報告 (第 4 回)職場での腰痛には心理・ 社会的要因も関与している, 産業医ジャーナル 33(1), pp. 60-66, 2010. 1

14) 村上正人他：筋骨格系の慢性疼痛, 総合臨床 59(11), pp. 2238-2248, 
2010

15) 篠崎哲也他: 肩こりの病態一アンケート調査より, 臨床整形外科 42 巻 5 号, pp. 409-412, 2007.5

16) 沓脱正計, 黒岩誠: 日本人が訴える肩こりの特徴について一欧米における neck pain との比較一, こころの健康第 25 巻第 2 号, pp. 61-66, 2010

17) 大谷晃司他 : 運動器に関する疫学調査一南会津スタディ第 3 報, 臨整外 44, pp. 49 54, 2009

18) 大谷晃司, 矢吹省司：肩こりの疫学と QOL への影響, Modern Physician 30 (2), pp. 232-234, 2010

19) 長澤夏子他:腰部負荷からみた手をつく立ち上がり動作 一加歯対応住宅 における腰部負担軽減を目的とした動作寸法体系の研究 その 1 一, 日 本建築学会計画系論文集, 第 586 号, pp. 51-56, 2004. 12

20) 長澤夏子他：腰部負担からみた収納動作 一加齢対応住宅における腰部負 担軽減を目的とした動作寸法体系の研究 その 2-, 日本建築学会計画 系論文集，第 605 号，pp. 71-77，2006

21) 長澤夏子他:在宅介護での移乗動作による腰部負荷の分析 一加齢対応住 宅における腰部負担軽減を目的とした動作寸法体系の研究 その 3 -, 日本建築学会計画系論文集, 第 613 号, pp. 81-87, 2007.3

22) 勝平純司他：階段の形状と手すりの使用が腰部モーメントに及ぼす影響, バイオメカニズム学会誌 Vol.29 No.2 pp. 95-103， 2005

23) 加藤龍一, 星且二：居住環境における健康維持増進に関する研究 (その 35）：エレベーターの無い団地の住居階数が自立高齢者の転倒、生存、外 出活動に及ぼす影響, 日本建築学会大会学術講演梗概集. D-1, pp. 1141-1142，2010

24) 総務省統計局: 人口推計, 2009

25) 総務省統計局: 人口推計, 2011
26) 日本整形外科学会:腰痛に関する全国調査, pp. 11-12, 2003

27) 長澤夏子, 加藤龍一他：居住環境における健康維持増進に関寸る研究 そ の 59, 居住環境および生活行動と腰痛の構造分析, 日本建築学会大会学 術講演梗概集、D-1分冊、pp. 1011〜 1012, 2012

28 ) 加藤龍一，長澤夏子他：居住環境における健康維持増進に関する研究 そ の 60 , 居住環境および生活行動と肩こりの構造分析, 日本建築学会大会 学術講演梗概集、D-1分冊、pp. 1013〜1014， 2012

29) 長澤夏子, 加藤龍一他: 居住環境における健康維持増進に関する研究 その 43 腰痛・肩こりの既往者に対する住環境・生活行動調査、日本建築学会 大会学術講演梗概集、D-1 分冊、pp. 1173-1174、2011

30) 加藤龍一, 長澤夏子他: 居住環境における健康維持増進に関する研究 その 44 キッチン作業からみた腰痛・肩こりの改善要因、日本建築学会大会学 術講演梗概集、D-1 分冊、pp. 1175-1176、2011

31) 朝野熙彦, 鈴木督久, 小島隆矢:入門 共分散構造分析の実際、講談社, 2005

32) 白土ら、疾患特異的・患者立脚型慢性腰痛症患者機能評価尺度; JLEQ (Japan Low back pain Evaluation Questionnaire) 、日本腰痛会誌, 13（J. Lumbar Spine Disord. 1)：225-235, 2007

33) 日本整形外科学会診断評価等基準委員会、日本春椎春髄病学会診断評価等 基準委員会作業部会、日本腰痛学会：JOA Back Pain Evaluation Questionnaire（JOABPEQ）：日本整形外科学会腰痛評価質問票、日本腰 痛会誌, 13 (J. Lumbar Spine Disord. 1)：208 - 224, 2007

34) 日本整形外科学会腰痛評価質問票、日本腰痛会誌, 13 (J. Lumbar Spine Disord. 1) : 208 - 224, 2007

(2012年 5 月10日原稿受理，2012年 9 月18日採用決定） 